\title{
Mendesain Meja Dan Kursi Ergonomi DenganMengacu Pada Nilai Antropometri Untuk Bagian Checking Rubber (Outsole) Di PT. Victory Chingluh Indonesia
}

\section{Designing Ergonomic Tables And Chairs By Referring To Anthropometric Values For The Checking Rubber (Outsole) Section At PT. Victory Chingluh Indonesia}

\author{
${ }^{1}$ Tri Widodo, ${ }^{2}$ Ismail Fardiansyah, ${ }^{3}$ Ali Gufron \\ 1,2,3 Program Studi Teknik Industri, Fakultas Teknik, Universitas Muhammadiyah Tangerang \\ Jl. Perintis Kemerdekaan I/33, Cikokol, Kota Tangerang \\ 1tri_wd@yahoo.com, ${ }^{2}$ fardiansyahismail@yahoo.com
}

\begin{abstract}
ABSTRAK
PT. Victory Chingluh Indonesia adalah perusahaan yang bergerakdibidang pembuatan sepatu olahraga yang bekerja sama dengan brand asal Amerika yaitu Nike. Dari hasil Kuesioner Nordic Body Map pada departemen PPIC RH bagian cheking ruber banyak pekerja mempunyai keluhan pada otot (musculoskeletal disorders) karena tempat kerja yang tidak ergonomi sebanyak 20pekerja atau $64,5 \%$ merasakan sakit dengan dengan kategori tinggi, sebanyak 8 pekerja atau 25,8\% merasakan sakit dengan kategori sedang, untuk kategori sakit dengan intensitas sangat tinggi sebanyak 2 pekerja atau 6,4\% dan 1 pekerja atau 3,2\% merasakan sakit dengan kategori rendah. Dari hasil tersebut maka perlu ada tindakan lanjut dengan membuat desain Working Furnitures (meja dan kursi) yang ergonimi dengan mengacu kepada nilai antropometri. Dengan acuan tersebut maka didapat desain meja dengan pajang $133,6 \mathrm{Cm}$ dengan menggunakan persentil 5- ${ }^{\text {th }}$, lebar meja $66,8 \mathrm{Cm}$ dengan persentil 5- ${ }^{\text {th }}$ dan tinggi meja 63,2 dan desain kursi mempunyai tinggi kursi 41,2 $\mathrm{Cm}$ dengan persentil 50-, Lebar alas kursi 40,5 Cm dengan persentil 95-th diharapkan pekerja yang memiliki lebar pinggul maksimal dapat menggunakan kursi tersebut, Panjang alas kursi 37,8 Cm dengan persentil 5-th , Tinggi sandaran kursi 54,5 Cm dengan persentil 50- ${ }^{\text {th }}$ dan Lebar sandaran kursi 48,9 Cm dengan persentil 95 - $^{\text {th }}$.
\end{abstract}

Kata Kunci: Ergonomi, Antropometri, musculoskeletal disorders. Nordic bodymap, desain.

\begin{abstract}
PT. Victory Chingluh Indonesia is a company engaged in the manufacture of sports shoes in collaboration with an American brand, namely Nike. From the results of the Nordic Body Map Questionnaire at the PPIC RH department of the checking ruber section, many workers have complaints in the muscles (musculoskeletal disorders) due to non-ergonomic workplaces as many as 20 workers or $64.5 \%$ feel pain in the high category, as many as 8 workers or 25 , $8 \%$ felt pain in the moderate category, for the category of pain with very high intensity as many as 2 workers or $6.4 \%$ and 1 worker or $3.2 \%$ felt pain in the low category. From these results, it is necessary to take further action by making ergonomic designs of Working Furnitures (tables and chairs) with reference to anthropometric values. With this reference, we get a table design with a length of 133.6 $\mathrm{cm}$ using the 5th percentile, a table width of $66.8 \mathrm{~cm}$ with a 5 th percentile and a table height of 63.2 and a chair design with a chair height of $41.2 \mathrm{~cm}$ with a 50th percentile. -, the width of the seat base is $40.5 \mathrm{~cm}$ with the 95th percentile, it is expected that workers who have a maximum hip width can use the chair, the length of the seat base is $37.8 \mathrm{~cm}$ with the 5th percentile, the height of the seat back is $54.5 \mathrm{~cm}$ with the 50th percentile th and the width of the seat backrest is $48.9 \mathrm{~cm}$ with the 95th percentile.
\end{abstract}

Keywords: Ergonomics, Anthropometry, musculoskeletal disorders. Nordic body map, design 


\section{PENDAHULUAN}

PT. Victory Chingluh Indonesia adalah sebuah perusahaan yang bergerak di bidang pembuatan sepatu olahraga yang bekerja sama dengan brand asal Amerika yaitu Nike. Dalam proses produksinya pada bagian checking rubber (outsole) ditemukan bahwa kondisi kerja yang dengan fasilitas yang kurang memadai mempercepat kelelahan dan menimbulkan keluhan sakit pada beberapa bagian tubuh (musculoskeletal disorders) sehingga kinerja tidak optimal. Keluhan pada sistem musculoskeletal disorders merupakan keluhan pada bagianbagian otot rangka yang dirasakan oleh seseorang, mulai dari keluhan sangat ringan sampai sangat sakit. Dari hasil wawancara yang dilakukan diketahui bahwa 90.32\% merasakan keluhan sakit, 6.45\% merasakan sangat sakit, dan 3.22\% merasakan tidak sakit.

pekerja yang kesehariannya bekerja dengan menggunakan meja dan kursi sebagai area kerjanya, sangat berpengaruh terhadap kesehatan pekerja yang secara tidak langsung dan berpengaruh pula terhadap hasil kerja yang tidak efisien. Berangkat dari fenomena ini maka penelitian dilakukan dengan judul mendesain meja Dan kursi ergonomi dengan mengacu pada nilai antropometri untuk bagian checking rubber (Outsole) Di Pt. Victory Chingluh Indonesia. Dengan adanya penelitian tersebut diharapkan mampu menghasilkan rancangan fasilitas kerja berupa meja dan kursi kerja (workingfurnitures) untuk pekerja yang ergonomis, sesuai dengan ukuran dimensi tubuh pekerja guna memperbaiki posisi kerja dan mengurangi ketidaknyamanan serta meminimalkan waktu pengecekan rubber (outsole) sehingga dapat meningkatkan output produksi.

\section{METODOLOGI PENELITIAN}

Metodologi penelitian yang dilakuan pada tahap awal adalah dengan melakukan pengumpulan data berupa observasi, kuisioner Nordic body map, dan pengukuran dimensi tubuh.lalu tahapan selanjutnya dengan melakukan teknik analisa data melalui hasil pengumpulan kuisioner, pembobotan, pengumpulan hasil pengukuran tubuh, analisa data pengukuran tubuh. dari hasil analisa yang dilakukan maka proses selanjutnya dengan mendesain gambar perancangan meja dan kursi. Tahapan-tahapan tersebut dapat dilihat secara detail pada gambar dibawah ini :

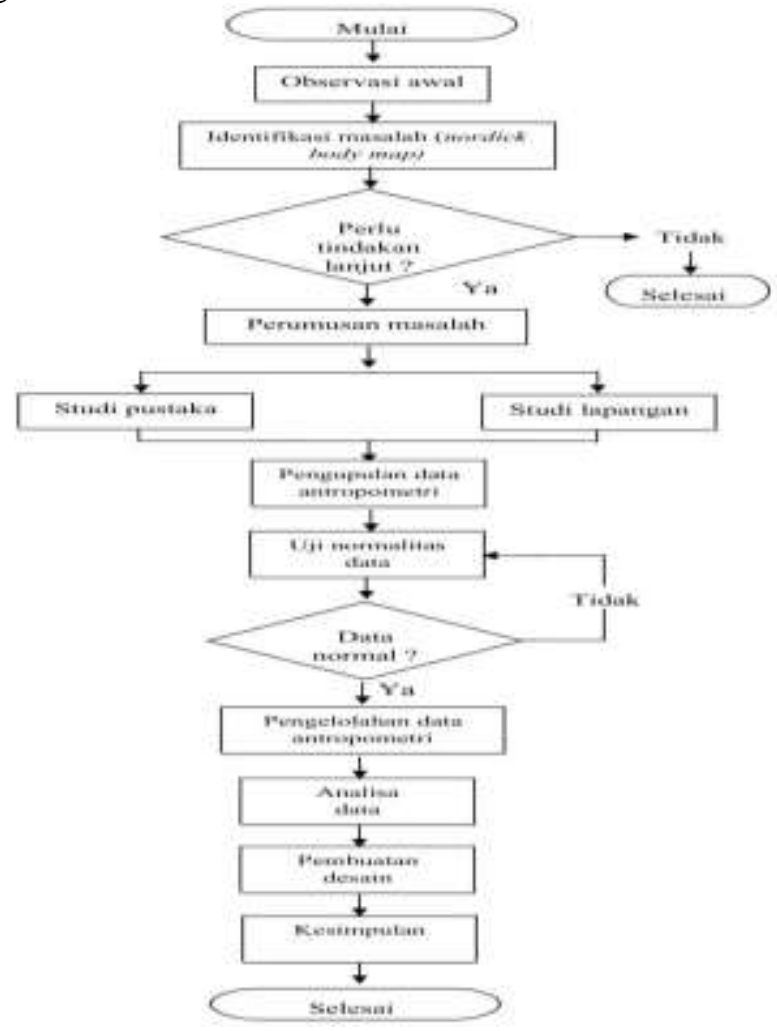

Gambar 1. Metodologi Penelitian 


\section{HASIL DAN PEMBAHASAN}

Hasil dan pembahasan menampilkan data yang didapat dan analisa sehingga menghasilkan desain gambar meja dan kursi kerja yang ergonomis.

\subsection{Identifikasi keluhan pekerja dengan Nordic Body Map (NBM)}

Pada tahapan ini dilakukan pengisian kuesioner Nordic body map yang diberikan kepada 31 pekerja yang melakukan proses cheking ruber. Kemudian dari hasil yang telah didapatkan dilanjut dengan melakukan skoring terhadap individu dengan skala likert yang telah ditetapkan. Skala tersebut berupa keterangan yang ada didalam kuesioner yaitu tidak sakit (tidak merasakan gangguan pada bagian tertentu) dengan skor 1, agak sakit (merasakan sedikit gangguan atau rasa nyeri pada bagian tertentu) dengan skor 2, sakit (merasakan ketidaknyamanan pada bagian tubuh tertentu) dengan skor 3, dan sangat sakit (merasakanketidaknyamanan pada bagian tertentu dengan skala yang tinggi) dengan skor 4. Dibawah ini adalah hasil pengolahan data dari kuisioner yang telah diberikan.

Tabel 1. Persentase Pekerja Yang Memiliki Keluhan Sakit ( $\mathrm{n}=31)$

\begin{tabular}{|c|c|c|c|c|c|c|}
\hline \multirow[b]{2}{*}{ NO } & \multirow[b]{2}{*}{ JENIS KELUHAN } & \multicolumn{4}{|c|}{ TINGKAT RASA SAKIT } & \multirow{2}{*}{$\begin{array}{c}\text { TOTA } \\
\text { L } \\
\text { S+SS }\end{array}$} \\
\hline & & $\mathrm{TS}$ & $\mathrm{AS}$ & $\mathrm{S}$ & SS & \\
\hline 0 & Sakit/kaku di leher atas & $1(3,2 \%)$ & $3(9,6 \%)$ & $5(16,1 \%)$ & $22(70,9 \%)$ & $27(87 \%)$ \\
\hline 1 & Sakit/kaku dileher bawah & $2(6,4 \%)$ & $0(0 \%)$ & $11(35,4 \%)$ & $18(58 \%)$ & $29(93,4 \%)$ \\
\hline 2 & Sakit di bahu kiri & $1(3,2 \%)$ & $8(25,8 \%)$ & $19(61,2 \%)$ & $3(9,6 \%)$ & $22(70,9 \%)$ \\
\hline 3 & Sakit di bahu kanan & $2(6,4 \%)$ & $10(32,2 \%)$ & $15(48,3 \%)$ & $4(12,9 \%)$ & $19(61,2 \%)$ \\
\hline 4 & Sakit pada lengan atas kiri & $3(9,6 \%)$ & $13(41,9 \%)$ & $12(38,7 \%)$ & $3(9,6 \%)$ & $15(48,3 \%)$ \\
\hline 5 & Sakit di punggung & $0(0 \%)$ & $1(3,2 \%)$ & $4(12,9 \%)$ & $26(83,8 \%)$ & $30(96,7 \%)$ \\
\hline 6 & $\begin{array}{l}\text { Sakit pada lengan atas } \\
\text { kanan }\end{array}$ & $4(12,9 \%)$ & $14(45,1 \%)$ & $11(35,4 \%)$ & $2(6,4 \%)$ & $13(41,9 \%)$ \\
\hline 7 & Sakit pada pinggang & $0(0 \%)$ & $1(3,2 \%)$ & $5(16,1 \%)$ & $25(80,6 \%)$ & $30(96,7 \%)$ \\
\hline 8 & Sakit pada bokong & $0(0 \%)$ & $3(9,6 \%)$ & $9(29 \%)$ & $19(61,2 \%)$ & $28(90 \%)$ \\
\hline 9 & Sakit pada pantat & $0(0 \%)$ & $2(6,4 \%)$ & $19(61,2 \%)$ & $10(32,2 \%)$ & $29(93,4 \%)$ \\
\hline 10 & Sakit pada siku kiri & $16(51,6 \%)$ & $10(32,2 \%)$ & $5(16,1 \%)$ & $0(0 \%)$ & $5(16,1 \%)$ \\
\hline 11 & Sakit pada siku kanan & $14(45,1 \%)$ & $8(25,8 \%)$ & $9(29 \%)$ & $0(0 \%)$ & $9(29 \%)$ \\
\hline 12 & Sakit di lengan bawah kiri & $2(6,4 \%)$ & $15(48,3 \%)$ & $12(38,7 \%)$ & $2(6,4 \%)$ & $14(45,1 \%)$ \\
\hline 13 & $\begin{array}{l}\text { Sakit di lengan bawah } \\
\text { kanan }\end{array}$ & $5(16,1 \%)$ & $14(45,1 \%)$ & $10(32,2 \%)$ & $2(6,4 \%)$ & $12(38,7 \%)$ \\
\hline 14 & $\begin{array}{l}\text { Sakit di pergelangan } \\
\text { tangan kiri }\end{array}$ & $7(22,5 \%)$ & $1(3,2 \%)$ & $15(48,3 \%)$ & $8(25,8 \%)$ & $23(74,1 \%)$ \\
\hline 15 & $\begin{array}{l}\text { Sakit di pergelangan } \\
\text { tangan kanan }\end{array}$ & $8(25,8 \%)$ & $1(3,2 \%)$ & $12(38,7 \%)$ & $10(32,2 \%)$ & $22(70,9 \%)$ \\
\hline 16 & Sakit pada tangan kiri & $2(6,4 \%)$ & $13(41,9 \%)$ & $11(35,4 \%)$ & $5(16,1 \%)$ & $16(51,6 \%)$ \\
\hline 17 & Sakit pada tangan kanan & $1(3,2 \%)$ & $13(41,9 \%)$ & $12(38,7 \%)$ & $5(16,1 \%)$ & $17(54,8 \%)$ \\
\hline 18 & Sakit pada paha kiri & $6(19,3 \%)$ & $9(29 \%)$ & $15(48,3 \%)$ & $1(3,2 \%)$ & $16(51,6 \%)$ \\
\hline 19 & Sakit pada paha kanan & $6(19,3 \%)$ & $11(35,4 \%)$ & $13(41,9 \%)$ & $1(3,2 \%)$ & $14(45,1 \%)$ \\
\hline 20 & Sakit pada lutut kiri & $6(19,3 \%)$ & $10(32,2 \%)$ & $7(22,5 \%)$ & $8(25,8 \%)$ & $15(48,3 \%)$ \\
\hline 21 & Sakit pada lutut kanan & $6(19,3 \%)$ & $10(32,2 \%)$ & $7(22,5 \%)$ & $8(25,8 \%)$ & $15(48,3 \%)$ \\
\hline 22 & Sakit pada betis kiri & $2(6,4 \%)$ & $4(12,9 \%)$ & $15(48,3 \%)$ & $10(32,2 \%)$ & $25(80,6 \%)$ \\
\hline 23 & Sakit pada betis kanan & $1(3,2 \%)$ & $1(3,2 \%)$ & $19(61,2 \%)$ & $10(32,2 \%)$ & $29(93,4 \%)$ \\
\hline 24 & Sakit pada pergelangankaki kiri & $7(22,5 \%)$ & $4(12,9 \%)$ & $15(48,3 \%)$ & $5(16,1 \%)$ & $20(64,5 \%)$ \\
\hline 25 & Sakit di pergelangan kakikana & $7(22,5 \%)$ & $3(9,6 \%)$ & $16(51,6 \%)$ & $5(16,1 \%)$ & $21(67,7 \%)$ \\
\hline 26 & Sakit pada kaki kiri & $2(6,4 \%)$ & $11(35,4 \%)$ & $8(25,8 \%)$ & $10(32,2 \%)$ & $18(58 \%)$ \\
\hline 27 & Saki pada kaki kanan & $3(9,6 \%)$ & $10(32,2 \%)$ & $8(25,8 \%)$ & $10(32,2 \%)$ & $18(58 \%)$ \\
\hline
\end{tabular}

Sumber: Kuesioner Pekerja Cheking Ruber, 2020

Dari tabel diatas dapat dilihat bahwa sebanyak 64,5\% merasakan sakit dengan dengan kategori tinggi sehingga diperlukan tindakan segera. Dan keluhan yang paling dominan dapat dilihat pada grafik dibawah ini : 


\section{Jumlah Keluhan Musculoskeletal Dengan Frekuensi Tertinggi}

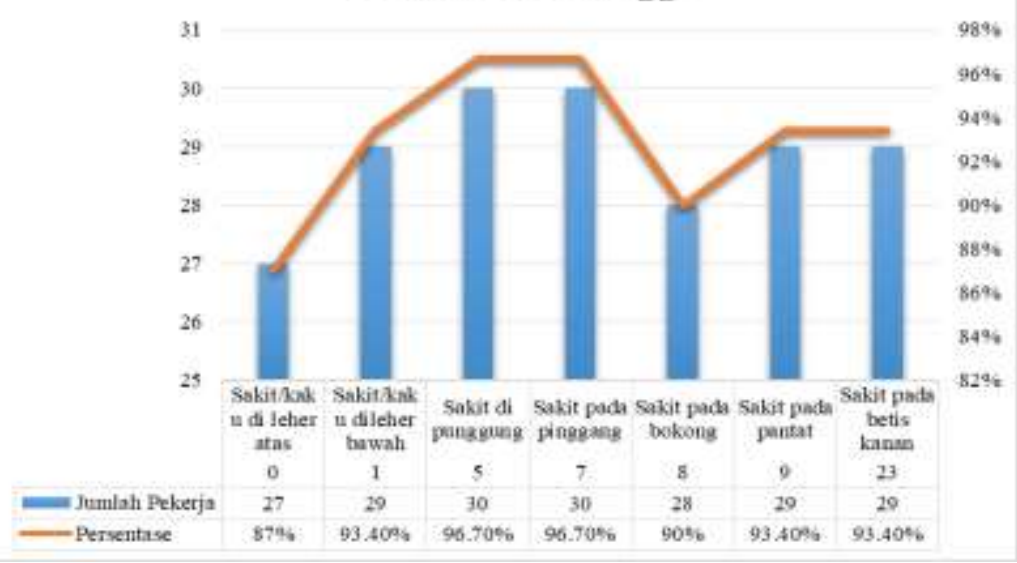

Gambar 2. Grafik Jumlah Keluhan Musculoskeletal Dengan Frekuensi Tertinggi

\subsection{Pengukuran Dimensi Tubuh}

Pengukuran dimensi tubuh statis mencakup pengukuran seluruh bagian tubuh dalam keadaan standard dan dalam keadaan diam baik dalam posisi berdiri maupun posisi duduk. Dalam penelitian ini pengukuran dimensi tubuh statis menjadi pilihan dikarnakan posisi pekerja yang selalu dalam keadaan duduk saat mereka melakukan pekerjaannya. Berikut adalah hasil pengukuran pekerja checking rubber :

Tabel 2. Data Antropometri Cheking Ruber (Total, Rata-Rata Dan Stdeviasi) dariTd ,Tsd,Tbd,TL dan Tpo

\begin{tabular}{|c|l|c|c|c|c|c|c|c|c|c|}
\hline & Td & Tsd & Tbd & TL & Tpo & Jhd & Pp & Ppp & Lb & Lp \\
\hline$\sum$ & 2,566 & 682 & 1,691 & 1,572 & 1,275 & 2,152 & 1,520 & 1,248 & 1,435 & 1,164 \\
\hline $\bar{X}$ & 82,7 & 22 & 54,5 & 50,7 & 41,2 & 69,4 & 49 & 40,2 & 46,2 & 37,5 \\
\hline SB ( & 3,18 & 1,86 & 2,60 & 1,59 & 2,01 & 1,52 & 1,44 & 1,41 & 1,65 & 1,84 \\
\hline
\end{tabular}

Sumber :Hasil Pengukuran pekerja Cheking Ruber, 2020

\subsection{Distribusi Normal}

Dari data diatas, maka selanjutnya dilakukan analisa distribusi normal menggunakan SPSS dengan hipotesis sebagai berikut :

Hipotesis:

H0 : Data berdistribusi normal

H1 : Data tidak berdistribusi normal

Statistik uji : Uji Kolmogorof-Smirnov

c. $\quad \alpha=0,05$

d. Daerah kritis : H0 ditolak jika Sig. $<\alpha$

dari hasil analisa distribusi normal yang dilakukan, dapat disimpulkan bahwa seluruh pengukuran memiliki keterangan data normal.

\section{Uji Keseragaman Data}

Selanjutnya data diolah dengan menguji keseragaman data menggunakan koefisien indeks tingkat kepercayaan, yaitu: $\mathrm{k}=95 \%=2$. Adapun hasil uji keseragaman data pengukuran antopometri menyatakan bahwa seluruh data seragam. 


\section{Uji Kecukupan Data}

Dalam uji kecukupan data antropometri tingkat kepercayaan yang digunakan adalah 95\% dan tingkat ketelitian sebesar 5\%. Dan hasil uji kecukupan data pada hasil pengukuran antopometri menyatakan bahwa data dinyatakan cukup.

\section{Perhitungan Persentil}

Ukuran persentil yang digunakan pada penelitian ini adalah 5 - $^{\text {th }}$ untuk persentil kecil, 50- ${ }^{\text {th }}$ untuk persentil rata-rata dan $95^{\text {th }}$ untuk ukuran persentil besar. Berikut merupakan perhitungan ukuran persentil untuk dimensi tinggi duduk (Td) :

$$
\begin{aligned}
& \mathrm{P} 5=\mathrm{Xbar}-1,645(\sigma) \\
& \begin{aligned}
\mathrm{P} 50 & =\mathrm{Xbar} \\
& =82,7
\end{aligned} \\
& \mathrm{P} 95=\text { Xbar }+1,645(\sigma) \\
& =82,7-1,645(3,18) \\
& =82,7+1,645(3,18) \\
& =77,4 \mathrm{Cm} \\
& =87,9 \mathrm{Cm}
\end{aligned}
$$

Adapun data ukuran persentil yang digunakan dapat dilihat pada tabel 4.25 berikut:

Tabel 3. Perhitungan Hasil Persentil $5-^{\text {Th }}, 50-^{\text {Th }}$ dan $95-^{\text {Th }}$

\begin{tabular}{|c|l|c|c|c|}
\hline \multirow{2}{*}{ No } & \multirow{2}{*}{ Pengukuran } & \multicolumn{3}{|c|}{ Persentil $(\mathbf{C m})$} \\
\cline { 3 - 5 } & & $\mathbf{5}^{\text {th }}(\mathbf{C m})$ & $\mathbf{5 0}-^{\text {th }}(\mathbf{C m})$ & $\mathbf{9 5}-^{\text {th }}(\mathbf{C m})$ \\
\hline 1 & Tinggi duduk & 77,4 & 82,7 & 87,9 \\
\hline 2 & Tinggi siku duduk & 18,9 & 22 & 25 \\
\hline 3 & Tinggi bahu duduk & 50,2 & 54,5 & 58,7 \\
\hline 4 & Tinggi lutut & 48 & 50,7 & 53,3 \\
\hline 5 & Tinggi popliteal & 37,8 & 41,2 & 44,5 \\
\hline 6 & Jakauan horizontal duduk & 66,8 & 69,4 & 71,9 \\
\hline 7 & Panjang paha & 46,6 & 49 & 51,3 \\
\hline 8 & Panjang popliteal paha & 37,8 & 40,2 & 42,5 \\
\hline 9 & Lebar bahu & 43,4 & 46,2 & 48,9 \\
\hline 10 & Lebar pinggul & 34,4 & 37,5 & 40,5 \\
\hline
\end{tabular}

Sumber : Hasil pengolahan data, 2020

\section{Desain Meja Kerja}

Setelah diketahui ukuran persentil, persentil maka selanjutnya adalah menentukanukuran meja yang sesuai dengan nilai antropometri yang didapat, berikut adalah ukuran desain meja:

Tabel 4. Ukuran Desain Meja

\begin{tabular}{|c|c|c|c|}
\hline No & Bagian Meja & PersentilKe & $\begin{array}{c}\text { Ukuran } \\
(\mathbf{C m})\end{array}$ \\
\hline 1 & Tinggi meja & 50- $^{\text {th }}$ & 63,2 \\
\hline 2 & Lebar meja & 5- $^{\text {th }}$ & 66,8 \\
\hline 3 & Panjang meja & 5- $^{\text {th }}$ & 133,6 \\
\hline
\end{tabular}

Sumber: Hasil pengolahan data, 2020 
Dengan desain meja kerja sebagai berikut:
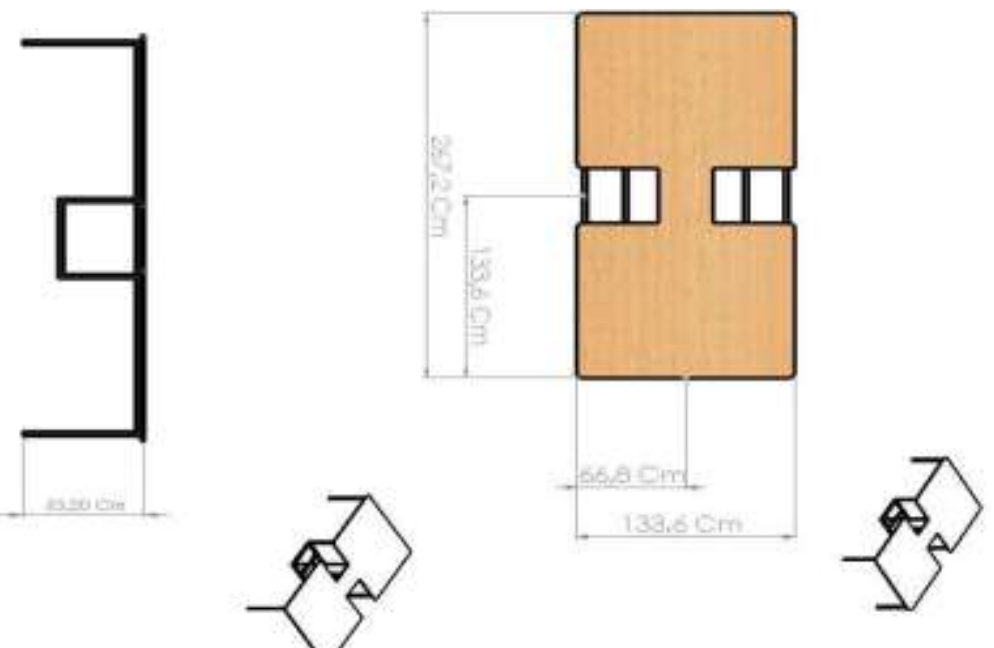

Gambar 3. Desain Meja Kerja

\section{Desain Kursi Kerja}

Menggunakan hasil perhitungan persentil yang didapat, selanjutnya dilakukan pembuatan kursi kerja dengan ukuran yang tertera pada tabel dibawah ini :

Tabel 5. Ukuran Desain Kursi

\begin{tabular}{|c|l|c|c|}
\hline No & Bagian Kursi & Persentil ke & Ukuran $(\mathbf{C m})$ \\
\hline 1 & Tinggi kursi & 50- $^{\text {th }}$ & 41,2 \\
\hline 2 & Lebar alas kursi & 95- $^{\text {th }}$ & 40,5 \\
\hline 3 & Panjang alas kursi & 5-th $^{\text {th }}$ & 37,8 \\
\hline 4 & Tinggi sandaran kursi & 50- $^{\text {th }}$ & 54,5 \\
\hline 5 & Lebar sandaran kursi & 95-th $^{\text {th }}$ & 48,9 \\
\hline
\end{tabular}

Sumber : Hasil pengolahan data, 2020

dengan desain gambar kursi sebagai berikut :

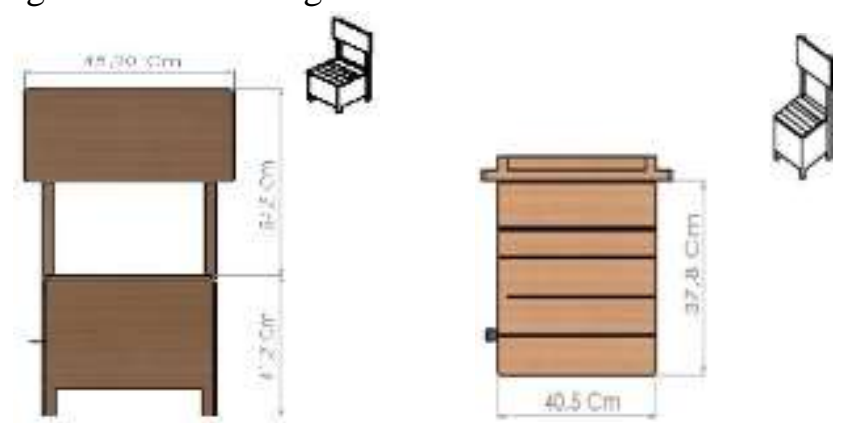

Gambar 4. Desain Kursi Kerja

\section{KESIMPULAN}

Setelah dilakukan pengolahan data dan analisa pada penelitian ini dapat disimpulkan bahwa :

1. Data yang didapat bahwa sebanyak $64.5 \%$ pekerja merasakan sakit dengan kategori yang sangat tinggi, maka keluhan pada otot (musculoskeletal disorders) pelu dilakukan tindakan segera.

2. Keluhan yang sering terjadi dengan frekuensi tinggi antara lain: sakit/kaku di leher atas sebanyak 27 pekerja (87\%), Sakit/kaku dileher bawah sebanyak 29 pekerja $(93,4 \%)$, Sakit di punggung sebanyak 30 pekerja $(96,7 \%)$, Sakit pada pinggang 
sebanyak 30 pekerja (96,7\%), Sakit pada bokong sebanyak 28 pekerja (90\%), Sakit pada pantat sebanyak 29 pekerja $(93,4 \%)$ dan Sakit pada betis kanan sebanyak 29 pekerja $(93,4 \%)$.

3. Dari hasil pengukuran dan analisa antopometri didapat bahwa ukuran ideal untuk desain meja dan kursi kerja antara lain:

a. Meja kerja: tinggi sebesar $63.2 \mathrm{~cm}$ dan lebar sebesar $88,8 \mathrm{~cm}$ serta panjang sebesar $133.6 \mathrm{~cm}$

b. Kursi Kerja: tinggi kursi sebesar 41,2 cm, lebar alas kursi sebesar 40,5 cm, Panjang alas kursi sebesar $37,8 \mathrm{~cm}$, tinggi sandaran kursi sebesar $54,5 \mathrm{~cm}$ dan lebar sandaran kursi sebesar 48,9 cm.

Saran yang bisa diberikan dari hasil penelitian ini adalah sebagai berikut:

1. pihak manajemen bisa mendapat gambaran seberapa besar para pekerja yang merasakan sakit akibat kerja dengan posisi yang tidak ergonomi dan dapat menggunakan desain ini sebagai acuan dalam memuat workfurniture yang lebih baik

2. para pekerja proaktif untuk memberikan komentar kepada manajemen jika merasakan keluhan-keluhan sakit yang diakibatkan karena posisi kerja dalam pelaksanaan proses produksinya

\section{DAFTAR PUSTAKA}

Abdul Rahman, S. (2017). Rancang Bangun Mesin Pengiris Ubi Kayu Menggunakan Pendekatan Nordic Body Map (Nbm) Dan Pendekatan Antropometri. Jurnal Industri .

Djamal, H., \& Kurniawan, M. F. (2019). Desain Alat Bantu Pengambilan Part Di Warehouse Pt . Xyz Dengan Aspek Ergonomi. Jisi: Jurnal Integrasi Sistem Industri, 6(2), 81-91.

Harahap, P., Huda, L., \& Pujangkoro, S. (2013). Analisis Ergonomi Redesain Meja Dan Kursi Siswa Sekolah Dasar. Jurnal Teknik Industri USU, 3(2), 38-44.

Hardinto, I dan Yassierli. (2017). Ergonomi Suatu Pengantar. Bandung : Pt. Remaja Rosdakarya Offset

Hari Purnomo. (2013). Antropometri Dan Aplikasinya. Yogyakarta : Graha Ilmu

Hasimjaya, J., Wibowo, M., \& Dodi Wondo. (2017). Kajian Antropometri \& Ergonomi Desain Mebel Pendidikan Anak Usia Dini 3-4 Tahun di Siwalankerto.Jurnal Intra, 5(2), 449-459.

Kurnia Wijaya. (2019). Identifikasi Risiko Ergonomi Dengan Metode Nordic Body Map Terhadap Pekerja Konveksi Sablon Baju. Seminar dan Konferensi NasionalIDEC ISSN: 2579-6429

Kristanto, A., \& Manopo, R. (2010). Perancangan Ulang Fasilitas Kerja Pada Stasiun Cutting Yang Ergonomis Guna Memperbaiki Posisi Kerja Operator Sebagai Upaya Peningkatan Produktivitas Kerja Studi kasus di Perusahaan Anode Crome Yogyakarta. Jurnal Informatika,4(2),467-479.

Nana Rahdiana. (2017). Identifikasi Risiko Ergonomi Operator Mesin Potong Guillotine Dengan Metode Nordic Body Map (Studi Kasus Di Pt. Xzy). Journal Industry Xplore - Vol. 02 No. 01,

Nurdian,E. \& Endang,D. (2017). Postur Kerja Dengan Keluhan Musculoskeletal Disorders Pada Pekerja Manual Handling Bagian Rolling Mill. The Indonesian Journal of Occupational Safety and Health, Vol. 6, No. 1 Jan-April 2017: 97-106

Prasetyo, E., \& Agri Suwandi. (2011). Rancangan Kursi Operator SPBU Yang Ergonomis Dengan Menggunakan Pendekatan Antropometri. Prosiding Seminar Nasional Dan Workshop Pemodelan Dan Perancangan Sistem 2011 ISBN 978602-19492-0-7, 169-177.

Putri, T. A., Ramadhan, M. N., \& Ma, M. (2018). Perancangan Kursi Kerja Menggunakan Pendekatan Antropometri sebagai Solusi Keterbatasan Ibu Hamil 
dalam Bekerja. Seminar Dan Konferensi Nasional IDEC, 7-8.

Ramdhani, D. (2018). Analisis Postur Kerja Pengrajin Handycraft Menggunakan Nordic Body Map Dan Metode Rapid Upper Limb Assessment (RULA) (Doctoral dissertation, Fakultas Teknik).

Sokhibi, A. (2017). Perancangan Kursi Ergonomis untuk Memperbaiki Posisi Kerja Pada Proses Packaging Jenang Kudus. Jurnal Rekayasa Sistem Industri, 3(1), 61-72.

Setyaningsih, L., Anna, B., \& Purbasari, A. (2016). Perancangan Footrest Untuk Mengurangi Kelelahan Operator pada Bagian Kaki di Cell S/A Coil XS156 di PT. ABC. Penelitian dan Aplikasi Sistem dan Teknik Industri, 10(2), 182900.

Setiawan, M. S., Hadyanawati, A. A., \& Suryoputro, M. R. (2019). Desain Meja, Kursi, dan Lampu yang Terintegrasi guna Menunjang Aktifitas Belajar. IENACO (Industrial Engineering National Conference).

Teguh, A. (2019). Desain Meja Dan Kursi Kerja Pengeleman Wallpaper Untuk Mengurangi Keluhan Kelelahan Muskuluskeletal.

Yanto \& Ngaliman. (2017). Ergonomi. Yogyakarta :C.V Andi Offset. 